\title{
BIM IMPLEMENTATION CHALLENGES FOR LATVIAN CONSTRUCTION INDUSTRY
}

\author{
Sandra Gusta, Arturs Neiburgs \\ Latvia University of Life Sciences and Technologies, Latvia \\ sandra.gusta@1lu.lv, arturs.neiburgs@gmail.com
}

\begin{abstract}
The article assesses and analyses the key challenges for the implementation of Building Information Modelling (BIM) in the Latvian construction industry, which, according to the BIM Implementation Roadmap, will be a mandatory requirement in certain public contracts from 2025 . In order to identify and analyse the main challenges, a survey was conducted to identify the current situation in the construction industry from a project management perspective. The study also includes data from other surveys conducted previously in Latvia on the industry's readiness to implement BIM and the costs of implementation. Latvia's situation is compared with the experience of other countries that have already completed certain stages of BIM implementation. The identified challenges demonstrate similarities with other countries experience, as well as highlight the specifics of Latvia. Although the construction industry is a highly technical industry, the key to BIM implementation is change management and communication. The development and traditions of the Latvian construction industry influence the general approach to the implementation of BIM, while at the organizational level the situation may differ significantly, requiring a specific approach and solutions. The study looks at various potential risks in the implementation of BIM and can serve as guidelines for the process of change in individual organizations, leaving the choice of change management methods to them.
\end{abstract}

Keywords: BIM implementation, Building Information Modelling, project management.

\section{Introduction}

The construction industry lags far behind other industries in terms of efficiency and the Building Information Modelling (BIM) methodology is considered to be a key factor to improve the situation. BIM is already being accepted globally and the BIM adoption rate in construction projects is significantly growing. Numerous studies and articles have been published on the implementation of BIM and its associated challenges, risks and benefits to projects, as well as potential future developments.

Literature research was conducted prior to the questionnaire to identify the specific BIM implementation challenges facing the Latvian construction industry. The selection of publications was based on the inclusion of different countries and time periods. It included publications from 20142020 and from 13 countries. The authors have investigated BIM-related problems using a variety of methods. It could be seen from the publications, that quite often their final conclusions coincide, regardless of the country's development index, social characteristics or traditions of the construction industry.

A Swedish study [1] looks at the role of the client in implementing BIM and promoting innovation. In one of the models described, the client takes the initiative to implement BIM and promote innovation. This contributes to accelerating the implementation of BIM, while at the same time creating some limitations. In the second model, competition between industry actors is a contributing factor. In this context, the authors have introduced the term "smart customer", which aims to promote competition by defining the goal to be achieved, but leaving the methods of achieving it to the performer.

Another study in Pakistan highlighted that the development of an overall strategy and roadmap for BIM implementation is as a key factor [2]. The strategy issues have also been a topic for Polish researchers in the SWOT analysis. They see that aggressive development strategy maximizing the use of strengths and opportunities will lead to better implementation results [3]. There are several hypotheses in the study of Singapore's motivational factors in the implementation of BIM. Two of them $(\mathrm{H} 10 \mathrm{a}$ and $\mathrm{H} 10 \mathrm{~B})$ emphasize the role of the state in adding value to the industry and facilitating implementation processes [4]. Studies by Swedish and French authors on the ability of small and medium-sized enterprises to implement BIM $[5 ; 6]$ show that they have little incentive to change. The solution would be for the state to introduce certain requirements that would force small and mediumsized enterprises to implement BIM and enhance their competitiveness. In the United Arab Emirates, the authors' conclusions mention the lack of standards, the lack of information on the benefits and the costs of BIM expected from public authorities, as the main challenges [7]. Every BIM implementer in 
the early stages has similar priorities to address. In Latvia, the first steps in BIM implementation have been taken in developing the BIM implementation road map. Work is underway on education reforms through introduction of BIM, standardization and adaptation, profession standard review, and other measures in line with the established strategy [8].

\section{Materials and methods}

At first, literature review was conducted to better assess the experience of BIM implementation in different countries. It also allows for a better assessment of the questions to be included in the survey. A quantitative method based on a survey was used to assess the challenges of BIM implementation challenges. The results were sorted and analysed using statistical methods. A questionnaire containing 22 questions was prepared and completed by 87 respondents.

By analysing selected literature and considering the authors' industry experience, the challenges of implementing BIM can be divided into three levels: strategy and roadmap development at national level, strategy at the organizational and project management level and project level implementation challenges. The survey questions cover the second-level challenges with a focus on project management. Its results are structured based on the first two questions, which allow all respondents to be grouped according to their role in construction projects and industry experience (Fig.1). In the group "Architecture", there is only one respondent, so this is not taken into account in the subsequent group evaluation. The questionnaire includes questions about the respondents' experience and role in projects, as well as what is the impact of the project manager on the project deadlines, costs and compliance with the customer's requirements. It also includes questions about planning, information delivery schedule, how BIM projects differ from conventional projects, what are the typical works in the project before it is handed over and what are the most important things to improve project efficiency. The questionnaire covers qualification, process and technology questions that address the three key elements of BIM (human, process, technology). The experience of other authors' surveys [915] was taken into account when compiling questions for the survey. It did not include questions related to implementation costs and the maturity of BIM organizations, since such studies have been done in Latvia in 2019 [16; 17].

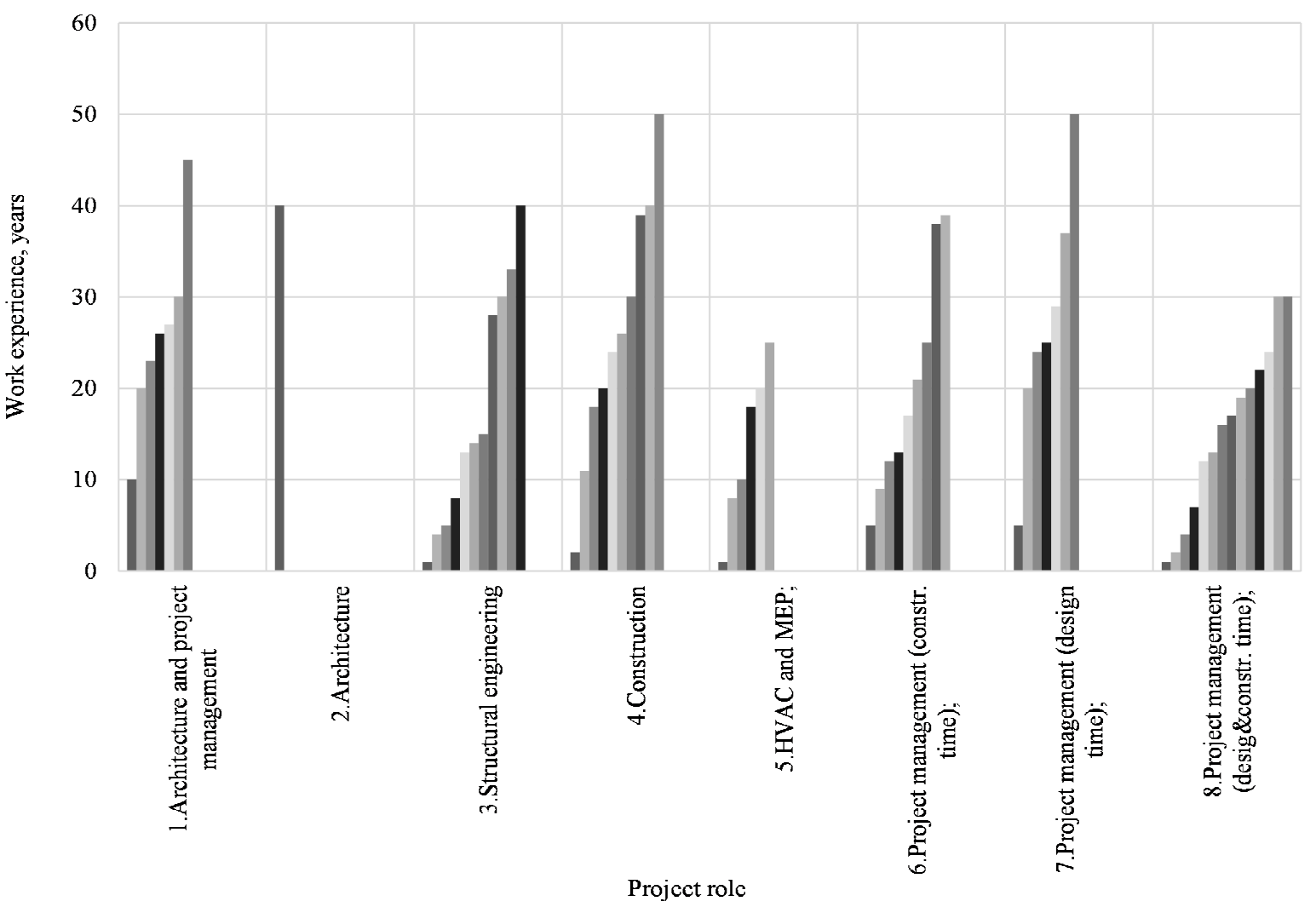

Fig. 1. Division of respondents in groups 
Evaluating the responses by groups, it shows significant differences of opinion about the project manager's ability to influence the processes. Respondents in all groups considered planning and project scheduling as an important project management tool, but often these schedules are not aligned and there is no information delivery plan. The most important factor in improving the efficiency of projects in all groups is that the client must not make changes to the project during the final phase of the project. Part of the survey answers by groups is summarized in Table 1, showing the most characteristic ones.

Table 1

\section{Part of the survey answers by groups [20-22]}

\begin{tabular}{|c|c|}
\hline Groups & Characteristic answers \\
\hline $\begin{array}{l}\text { 1. Architecture and } \\
\text { project management }\end{array}$ & $\begin{array}{l}- \text { Respondents who agree that the project manager (PM) is capable of } \\
\text { meeting project requirements *, deadlines } * * \text { and costs } * * * \text { respectively } \\
40.0 \% *, 30 \% * * \text { un } 30 \% \\
\text { - Respondents who have used common data environment }(\mathrm{CDE}) * \text { and } 3 \mathrm{D} \\
\text { models in project meeting** compile accordingly } 90 \% * \text { un } 80 \% * *\end{array}$ \\
\hline $\begin{array}{l}\text { 3. Structural } \\
\text { engineering }\end{array}$ & $\begin{array}{l}\text { - Respondents who agree that PM is capable of meeting project requirements } \\
* \text {, deadlines } * * \text { and costs } * * * \text { respectively } 35.3 \% *, 29.4 \% * * \text { un } 17.6 \% \\
\text { - Respondents who have used common data environment (CDE)* and 3D } \\
\text { models in project meeting** compile accordingly } 76.5 \% * \text { un } 94.1 \% * *\end{array}$ \\
\hline 4. Construction & $\begin{array}{l}- \text { Respondents who agree that PM is capable of meeting project requirements } \\
* \text {, deadlines } * * \text { and costs } * * * \text { respectively } 10.0 \% *, 10 \% * * \text { un } 0 \% \\
\text { - Respondents who have used common data environment (CDE)* and 3D } \\
\text { models in project meeting** compile accordingly } 30.0 \% * \text { un } 30.0 \% * *\end{array}$ \\
\hline 5. HVAC and MEP & $\begin{array}{l}\text { - Respondents who agree that PM is capable of meeting project requirements } \\
* \text {, deadlines } * * \text { and costs } * * * \text { respectively } 57.1 \% *, 42.9 \% * * \text { un } 14.3 \% \\
\text { - Respondents who have used common data environment (CDE)* and 3D } \\
\text { models in project meeting** compile accordingly } 85.7 \% * \text { un } 57.1 \% * *\end{array}$ \\
\hline $\begin{array}{l}\text { 6. Project } \\
\text { management (constr. } \\
\text { time) }\end{array}$ & $\begin{array}{l}\text { - Respondents who agree that PM is capable of meeting project requirements } \\
* \text {, deadlines } * * \text { and costs } * * * \text { respectively } 55.5 \% *, 44.4 \% * * \text { un } 22.2 \% \\
\text { - Respondents who have used common data environment }(\mathrm{CDE}) * \text { and 3D } \\
\text { models in project meeting** compile accordingly } 55.5 \% * \text { un } 55.5 \% * *\end{array}$ \\
\hline $\begin{array}{l}\text { 7. Project } \\
\text { management (design } \\
\text { time) }\end{array}$ & $\begin{array}{l}\text { - Respondents who agree that PM is capable of meeting project requirements } \\
* \text {, deadlines } * * \text { and costs } * * * \text { respectively } 70.0 \% *, 40 \% * * \text { un } 20 \% \\
\text { - Respondents who have used common data environment (CDE)* and 3D } \\
\text { models in project meeting** compile accordingly } 90 \% * \text { un } 70 \% * *\end{array}$ \\
\hline $\begin{array}{l}\text { 8. Project } \\
\text { management (design } \\
\text { and constr. time) }\end{array}$ & $\begin{array}{l}\text { - Respondents who agree that PM is capable of meeting project requirements } \\
* \text {, deadlines } * * \text { and costs } * * * \text { respectively } 47.8 \% *, 34.8 \% * * \text { un } 26.1 \% \\
\text { - Respondents who have used common data environment }(\mathrm{CDE})^{*} \text { and } 3 \mathrm{D} \\
\text { models in project meeting** compile accordingly } 78.3 \% * \text { un } 56.5 \% * *\end{array}$ \\
\hline
\end{tabular}

Similar ideas are considered in the works of authors from other countries [18].

\section{Results and discussions}

Analysing the results of the survey, in the context of other surveys and studies, leads to several conclusions. They highlight the complexity of the topic that requires a diversified approach to the successful implementation of BIM. One of the most common complex problem-solving techniques is to split it into smaller, simpler problems. For further discussions and researches, the authors propose to divide the problem under investigation according to the theory of innovation diffusion [19]. In practice, this would mean exploring the specific challenges for each project role, facing each group of innovation adapters and which methods would be more effective in promoting BIM (Fig.2). For example, builders' innovators $(2.5 \%)$ and early adopters $(13.5 \%)$ are sufficiently motivated to innovate, support is needed to commercialize ideas and create an innovative environment. Builders' laggards $(16 \%)$ on the opposite need additional motivation for BIM adaptation. That may be mandatory BIM requirements for public construction projects. 


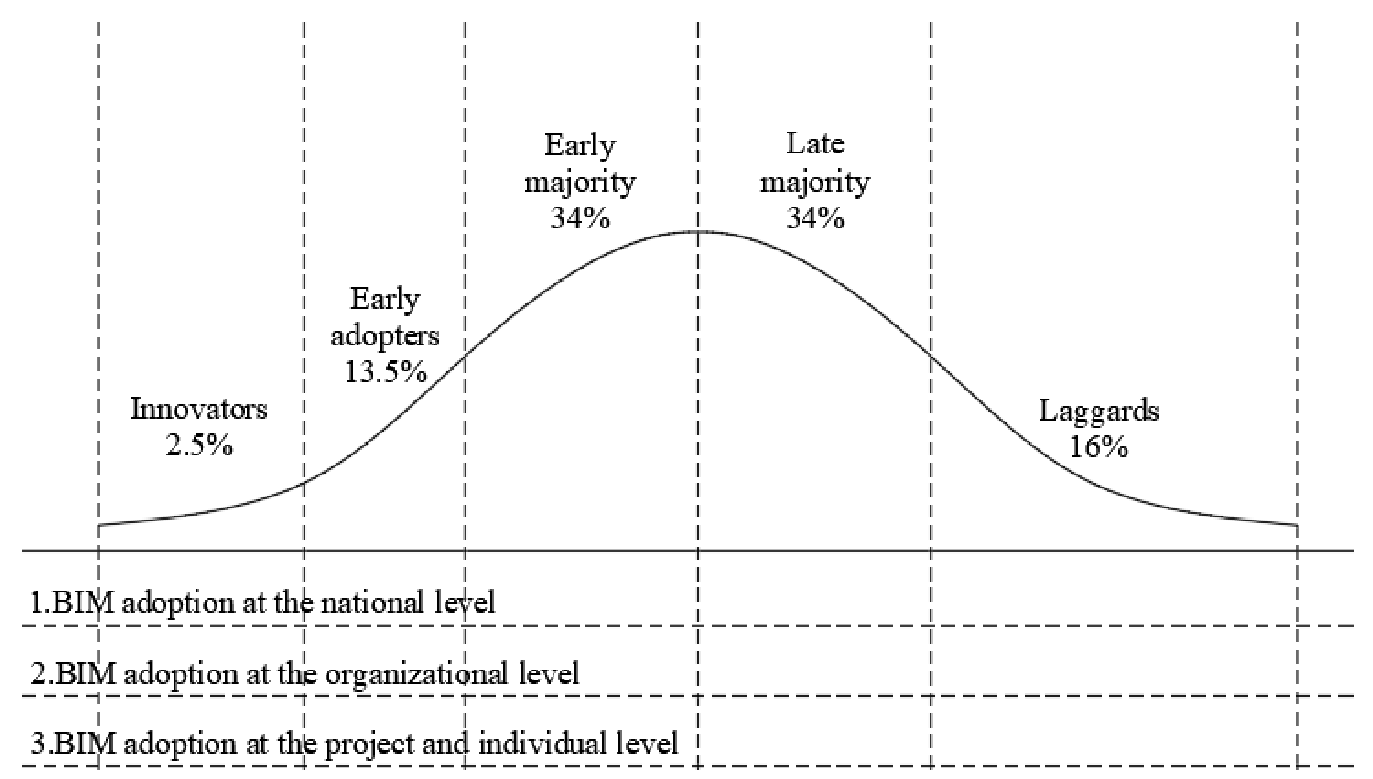

Fig. 2. Division of respondents into groups

The results of the study on typical BIM implementation challenges for the Latvian construction industry from the perspective of construction project management are summarized in Table 2.

Table 2

Results of the study on typical BIM implementation challenges for the Latvian construction industry from the perspective of construction project management [20-22]

\begin{tabular}{|c|l|c|c|c|c|c|c|c|}
\hline No. & \multicolumn{1}{|c|}{ Characteristic challenge $\backslash$ Survey group } & $\mathbf{1}$ & $\mathbf{3}$ & $\mathbf{4}$ & $\mathbf{5}$ & $\mathbf{6}$ & $\mathbf{7}$ & $\mathbf{8}$ \\
\hline 1. & Project manager qualifications and knowledge on BIM. & & & & + & + & + & + \\
\hline 2. & Strengthening the role of PM in construction projects. & + & + & + & & & & + \\
\hline 3. & Project process changes according to BIM principles. & & & + & & & & \\
\hline 4. & $\begin{array}{l}\text { Implementation of information delivery schedule in } \\
\text { projects }\end{array}$ & + & + & + & + & + & + & + \\
\hline 5. & Implementation of the BIM Execution Plan (BEP) & + & + & + & + & + & + & + \\
\hline 6. & $\begin{array}{l}\text { Implementation of CDE and 3D model technologies in } \\
\text { the everyday work process. }\end{array}$ & & & + & & & & \\
\hline 7. & $\begin{array}{l}\text { More precise definition of the Employer's Information } \\
\text { Requirements (EIR) and design task. }\end{array}$ & + & + & + & & + & + & \\
\hline
\end{tabular}

The amount of experience influences how the industry professional perceives implementation of changes in the industry. Professionals with greater industry experience tend to rely on their own expertise rather than acquiring new knowledge. Such inflexible approach creates difficulties in the implementation of BIM and requires a special approach. One of such approaches can be to bring together experienced project specialists with the ones who are more technologically advanced. To succeed, motivation from both to learn is still needed.

Planning and scheduling are highlighted as a key factor for successful project implementation in all survey groups. From a BIM perspective, planning is addressed in the BIM implementation plan and information delivery schedule, some adjustments to existing processes need to be done. Another important factor that hinders improvement of project results is that the client makes changes to the EIR's and design task quite often during the final phase of the project. Typically, such changes are due to the fact that, at the final phase of the project, the customer will have a better insight of the building. It mostly turns out that building does not provide the planned processes during the operation of the building or need some other improvements. The biggest challenge here is to show the client the most 
realistic building solutions at the earliest possible stage of the project. This can be done by involving all project parties at an earlier stage of the project (design in minimal composition or sketch phase), using different technologies (e.g. visualization, virtual reality, augmented reality, simulations of operational processes) that allow the customer to better understand the building or structure expected.

Other questions show differences between the survey groups. Builders are more concerned with learning and implementing technology in day-to-day processes, while project management, HVAC and MEP engineers think PM should have in-depth training and knowledge of BIM. More attention needs to be paid to the digitalisation of builders and their integration into BIM processes, as they lag behind designers. At the same time, the builders are the ones who can reap significant benefits from BIM projects.

\section{Conclusions}

1. The project managers' role should be strengthened and they should be motivated to acquire new professional knowledge, including on BIM.

2. New processes according to BIM must be implemented at the design stage to promote collaborative environment at early project stages.

3. Technology adaptation in the construction process should be significantly promoted. Builders lag behind designers, but the construction phase has the potential to benefit greatly from digitalization.

4. Encouragement of early involvement of project participants in the project. Application of technology to provide the customer with a more accurate insight and understanding of the expected building and its compliance with operational requirements. This would significantly reduce the amount of design changes during the design phase and during construction.

\section{References}

[1] Lindblad H., Rudolphsson G. J. Client's role in promoting BIM implementation and innovation in construction. Journal Construction Management and Economics, vol. 38, 2020, issue 5: Building Information and Modelling, pp. 468-482.

[2] Girginkaya Akdag S., Maqsood U. A roadmap for BIM adoption and implementation in developing countries: the Pakistan case. Archnet-IJAR: International Journal of Architectural Research, vol. 14, No. 1, 2020, pp. 112-132.

[3] Zima K., Plebankiewicz E., Wieczorek.D. A SWOT Analysis of the Use of BIM Technology in the Polish Construction Industry. Journal Buildings, 2020, pp. 10- 16.

[4] Yuan H., Yang Y., Xue X. Promoting Owners' BIM Adoption Behaviors to Achieve Sustainable Project Management. Open access journal Sustainability, 2019, 11, 3905.

[5] Bosch-Sijtsema P., Isaksson A. Lennartsson M., Linderoth H.C.J. Barriers and facilitators for BIM use among Swedish medium-sized contractors - "We wait until someone tells us to use it". Bosch-Sijtsema et al. Visualization in Engineering, vol. 5, article No 3, 2017.

[6] Tranchant A., Beladjine D., Lineact K.B. BIM in French SMES: From innovation to necessity. www.witpress.com, WIT Transactions on The Built Environment, vol 169, 2017, pp. 135-142.

[7] Mehran D. Exploring the Adoption of BIM in the UAE construction industry for AEC firms. International Conference on Sustainable Design, Engineering and Construction 2016. Procedia Engineering, vol. 145, 2016, pp. 1110-1118.

[8] Gusta S., Strausa S., Freimanis J. BIM opportunities and challenges in construction study programs at Latvia University of Life Sciences and Technologies International conference "Engineering for Rural Development", May 23-25, 2018, Jelgava Latvia, pp. 1204.-1212.

[9] Ozturk G.B. The Relationship Between BIM Implementation and Individual Level Collaboration in Construction Projects. 2019 IOP Conf. Ser.: Mater. Sci. Eng. 471022042.

[10] Smith P. BIM implementation - global strategies. Creative Construction Conference 2014, CC2014. Procedia Engineering 85, 2014, pp. 482-492.

[11] Mirarchi C., Trebbi C., Spagnolo S.L., Daniotti B., Pavan A., Tripodi D. BIM Methodology and Tools Implementation for Construction Companies (Green BIM Project). B. Daniotti et al. (eds.), Digital Transformation of the Design, Construction and Management Processes of the Built Environment, Research for Development,2020, pp. 201.-208. 
[12] Alazmeh N., Underwood J., Coates P. Implementing a BIM collaborative workflow in the UK construction market. WIT Press journal, vol. 13, issue 1, 2018, pp.24.-35.

[13] Mohammed A. Enshassi, Khalid A. Al Hallaq, Bassam A. Tayeh. Limitation Factors of Building Information Modeling (BIM) Implementation. The Open Construction \& Building Technology Journal, vol.13, 2019, pp. 189-196.

[14]Longhui Liao, Evelyn Ai Lin Teo, Ruidong Chang. Reducing Critical Hindrances to Building Information Modeling Implementation: The Case of the Singapore Construction Industry. Applied Science. vol. 9, 2019, 3833.

[15]Di Bari R., Jorgji O., Horn R., Gantner J., Ebertshäuser S. Step-by-step implementation of BIMLCA: A case study analysis associating defined construction phases with their respective environmental impacts. IOP Conf. Ser.: Earth Environ. Sci. vol. 323, 2019, 012105.

[16] Šḳiltere D. Danusēvičs M., Brasliṇa L., Batraga A. Ieguldījumu novērtējums būvju informācijas modelēšanas (BIM) ieviešanai būvniecības pasūtītāju, projektěšanas un būvniecības uzṇēmumos. (Investment evaluation of building information modeling (BIM) implementation for construction clients, design and construction contractors) 2019. (In Latvian)

[17]Lielā BIM skaitı̌šana. 2019. (Large BIM counting. 2019.) (In Latvian). [online] [05.09.2020]. Available at: https://www.lielabimskaitisana.lv

[18] Mohamed H. Shaban, Ashraf Elhendawi. Building Information Modeling in Syria: Obstacles and Requirements for Applying. International Journal of BIM, and Engineering Science, vol. 1, issue 1, 2018, pp. 42.-64.

[19] Rogers E, Diffusion of innovations, 1962. 1971, 1983 by The Free Press A Division of Macmillan Publishing Co., Inc., 1983, 453 p.

[20] Aptauja - projekta vadības loma BIM ieviešanā būvprojektos. (Survey - the role of project management in the implementation of BIM in construction projects) (In Latvian). [online] [05.09.2020]. Available at: https://www.buvniekupadome.lv/notikums/aptauja-projekta-vadibasloma-bim-ieviesana-buvprojektos

[21] Rīko aptauju par BIM projektu vadību. (Conducts a survey on BIM project management) (In Latvian). [online] [05.09.2020]. Available at: http://buvinzenierusavieniba.lv/riko-aptauju-parbim-projektu-vadibu

[22] LLU veic pētījumu par būvniecības informācijas modelēšanas ieviešanas izaicinājumiem. (LUA is conducting a study on the challenges of implementing construction information modelling) (In Latvian). [online] [04.02.2020]. Available at: https://zurnalsiepirkumi.lv/llu-veic-petijumu-parbuvniecibas-informacijas-modelesanas-ieviesanas-izaicinajumiem-nozare 